Names, Vol. 38, No. 3 (September 1990)

\title{
The U.S. Board on Geographic Names and Its Work in Foreign Areas
}

\section{Richard R. Randall}

\begin{abstract}
Through its Foreign Names Committee and other bodies, the U.S. Board on Geographic Names has standardized names of places and features in other countries, in undersea areas, and in Antarctica. These names are available for Federal agencies and other users in some $\mathbf{1 7 5}$ gazetteers, which present alphabetic listings of names and associated locational information for each country or area. An important part of the work of the Foreign Names Committee has been to develop methods for spelling romanized forms of geographic names in countries using a variety of non-roman writing systems.
\end{abstract}

\section{$* * * * *$ \\ Introduction}

The one hundredth anniversary of the U. S. Board on Geographic Names (BGN) is an appropriate time to recognize the contributions of its members, its staff, and its functioning arms. Over the years, a number of Board committees have carried out important tasks, and a complete inventory of these bodies and their accomplishments would require a sizable tome. This paper focusses attention on one highly significant area, the work of the Board on names in foreign areas-including the Board's growing focus on foreign names, its work during World War II, and a greatly expanded concern when the Board was reestablished after the War. In addition, the paper outlines the function of the Foreign Names Committee and its staff in providing standardized names, defines the activities of other committees involved in foreign names (names of places outside the United States), and briefly discusses the Board's work at the international level.

\section{Early Work on Names Outside the United States}

President Harrison's decree creating the U.S. Board on Geographic Names in 1890 did not specify geographic areas where that organization's 


\section{Richard R. Randall}

mission was to apply. Certainly, the difficulties long encountered in naming places in the United States were the principal reason for establishing the Board, but the requirement to deal with names in foreign areas was also anticipated. One clue is that among the first Board members were representatives of the Departments of State, War, and Navy. Although these agencies had missions in the U.S., their functions in foreign areas indicate a recognition of a need to deal with names outside the country as well.

Initial programs did in fact focus on domestic names actions, but work increasingly concentrated on foreign names. The Board's Third Report, ${ }^{1}$ published in 1906, was the first to discuss concerns with names in other countries. The report said, "... the work of the Board is directed toward the harmonization of American usage in geographic nomenclature with the usage of the great map making nations - England, Germany, and France." It also described the needs of the Department of State in diplomatic and consular affairs and the Navy's need to have consistent spellings of names on charts to help ensure safe navigation to foreign ports. The report also discussed foreign names that require transliteration, or the change of non-roman-alphabet spellings to equivalent roman-letter spellings.

The Fourth Report of 1916 listed some 14,000 decisions the Board had rendered (of which perhaps no more than about two percent were for names outside the continental United States.) The Fifth Report of 1920 showed a growing involvement with foreign names: it contained a greater percentage of foreign names and included a system for transliterating Russian alphabetic characters to spell placenames.

In 1932 the Sixth Report dealt even more fully with foreign names. For the first time a complete section on foreign geographic names was written and sections described spelling policies for Greek, Turkish (of considerable interest because in 1928 Turkey adopted a new alphabet of Latin characters), and Japanese and also offered commentary on additional languages. The report included decisions on approximately 29,000 places, about ten percent of which were outside the United States. While little work on foreign names was being carried out in the late 1930s, the Board had clearly demonstrated its vision.

\section{The Board and World War II}

By 1943, the requirements for geographic names on military maps of China, Japan, and Korea prompted the Secretary of the Interior to call 
for a large staff of names experts. They were needed to develop systems to convert the spellings of geographic names in Chinese and Japanese and other oriental writing systems to roman versions for use by U.S. cartographers. By the end of the War, the organization in Washington had a staff of 162 geographers, cartographers, and linguists who produced some three million names for maps and charts.

\section{The Reestablishment of the Board in 1947}

While a number of agencies in Washington closed operations at the end of the War, federal officials saw a continuing need for names standardization, and on September 4, 1947, the 80th Congress reestablished the Board by Public Law 242. Like the Presidential Decree of 1890, the law identified agencies responsible for providing members, but it specified its mandate and overall operational procedures in greater detail. One key provision was that the Secretary of the Interior and the Board had "conjoint" responsibilities for names standardization. This relationship was agreed to as a means of giving due prominence to the work of the Board, whose name officially became the $U$. S. Board on Geographic Names.

An early task was to create committees to carry out the Board's functions. With the experience of World War II behind it, members agreed that a key committee would be one for foreign names.

\section{The BGN Foreign Names Committee}

The Foreign Names Committee (FNC) was - and is - composed of members from federal agencies responsible for maps, charts, and reports of foreign areas. Current members represent the Department of State, the Department of Defense, the Central Intelligence Agency, and the Library of Congress. The new committee worked with a staff of some sixty-five persons and initiated programs to prepare files of geographic names in each foreign country and area of the world. While cartographic usage remained important, the names were also required for area studies then required by various federal departments. Typical titles were Austria, The Caribbean, and The Arabian Peninsula. By about 1965, the FNC had standardized about four million names and had published them in some 170 country or area gazetteers.

At present, the FNC and its staff, while continuing to publish gazetteers, also carry out other functions: they edit maps and charts of foreign 
areas produced by U.S. agencies to assure that names conform to spellings approved by the Committee on behalf of the Board; they respond to inquiries from federal offices and outside organizations (including private individuals) for information about names; they prepare studies on geographic names for various conferences.

To carry out its assignments, the staff monitors world patterns of name changing and prepares papers for Committee review. The Committee meets three or four times a year to conduct business. As of July 10, 1990, the Committee had met 284 times. Because of the thousands of names that could require extensive FNC action, by agreement the staff brings only certain categories of names to the Committee, namely, country names, names of first-order administrative entities (such as states or provinces), and international features (common to two or more countries). Figure 1 is a typical FNC staff paper. On the other hand, and in accordance with procedures approved by the Committee, the staff is responsible for dealing with new or changed names of all other geographic features and making decisions to approve them. The staff will bring to the Committee, however, any question of unusual importance. At present, the staff has about forty persons with backgrounds in geography, cartography, and languages. Linguists are also involved. It is important to note that by working in a field for which there is little or no traditional training, the staff members have helped shape a new discipline that has become known as "toponymy."

The FNC mission to "standardize" foreign names does not mean that it actually names features in foreign countries. Whenever possible, the committee accepts local names. There may be occasions when the staff (or Committee) is not able to resolve evidence about new or changed names. In such cases, the committee closely examines conflicting or confusing information and material and makes a decision to select the most appropriate name as a standard name.

\section{Promulgating Information about Standardized Names}

The results of the FNC standardization process are promulgated in several ways. The most usable way is through gazetteers, which now make up a library of some 175 volumes covering individual foreign countries and regions. Originally of limited distribution, gazetteers are now available to all users, albeit at a price to those outside specified federal offices. Altogether these gazeteers contain about 4.5 million names for perhaps three 


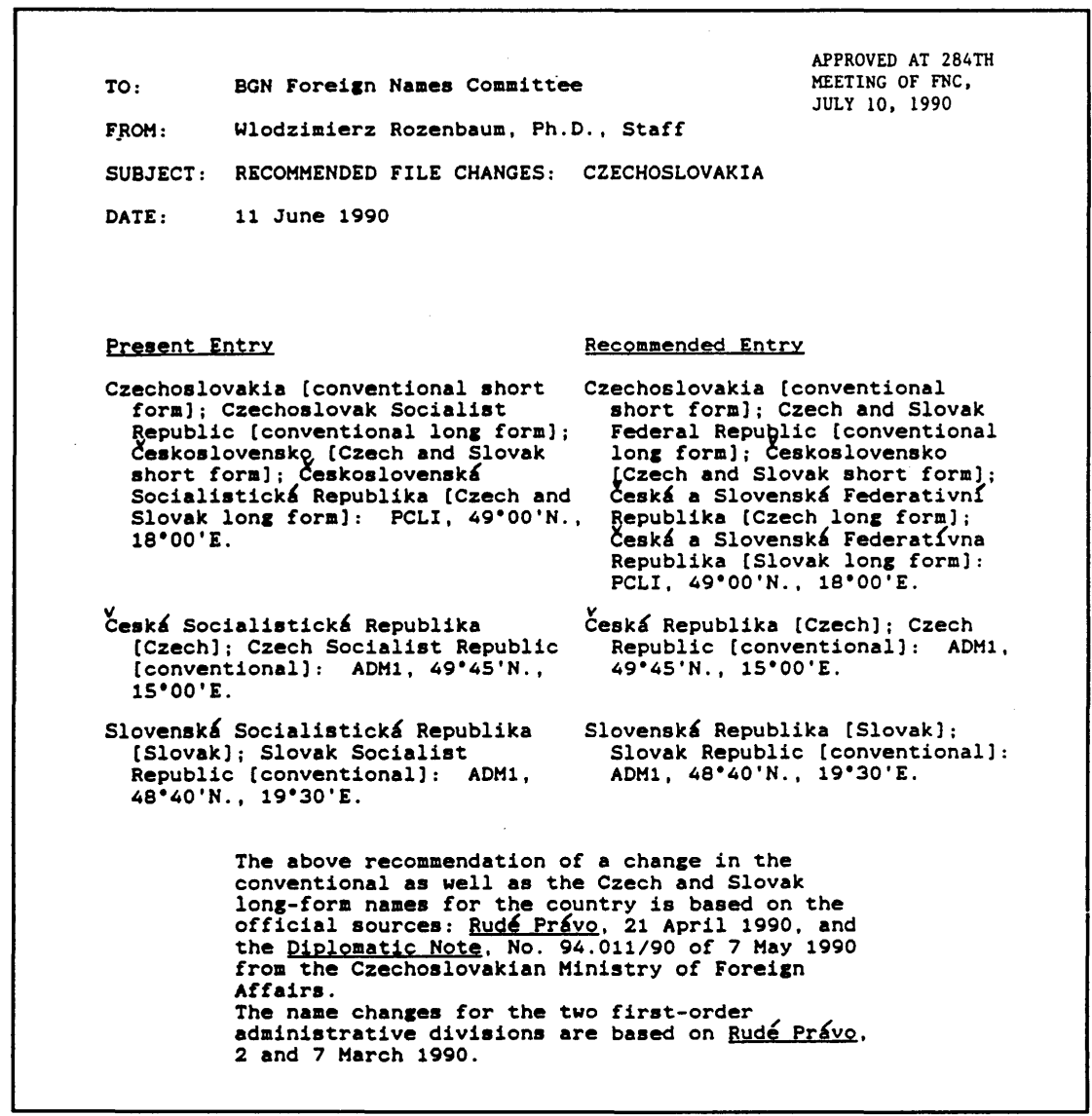

Fig. 1. Facsimile of a page from a recent FNC meeting concerning name change for Czechoslovakia.

million features; the difference comes about because, in addition to the name approved by the Board, many features also carry a variant name (a former name or one also in some local usage). The fact that many areas of the world experience changes means that gazetteers must be revised periodically. About five are issued each year, and some are now in their third edition. BGN gazetteers are unique and may be found as basic source documents in major libraries on a worldwide basis. Figure 2 is a page from the 1989 edition of the gazetteer of Colombia.

Minutes of FNC meetings are a more timely way to promulgate information to members and their agencies. The Committee also publishes its names decisions periodically in Foreign Names Decisions of the 


\section{Richard R. Randall}

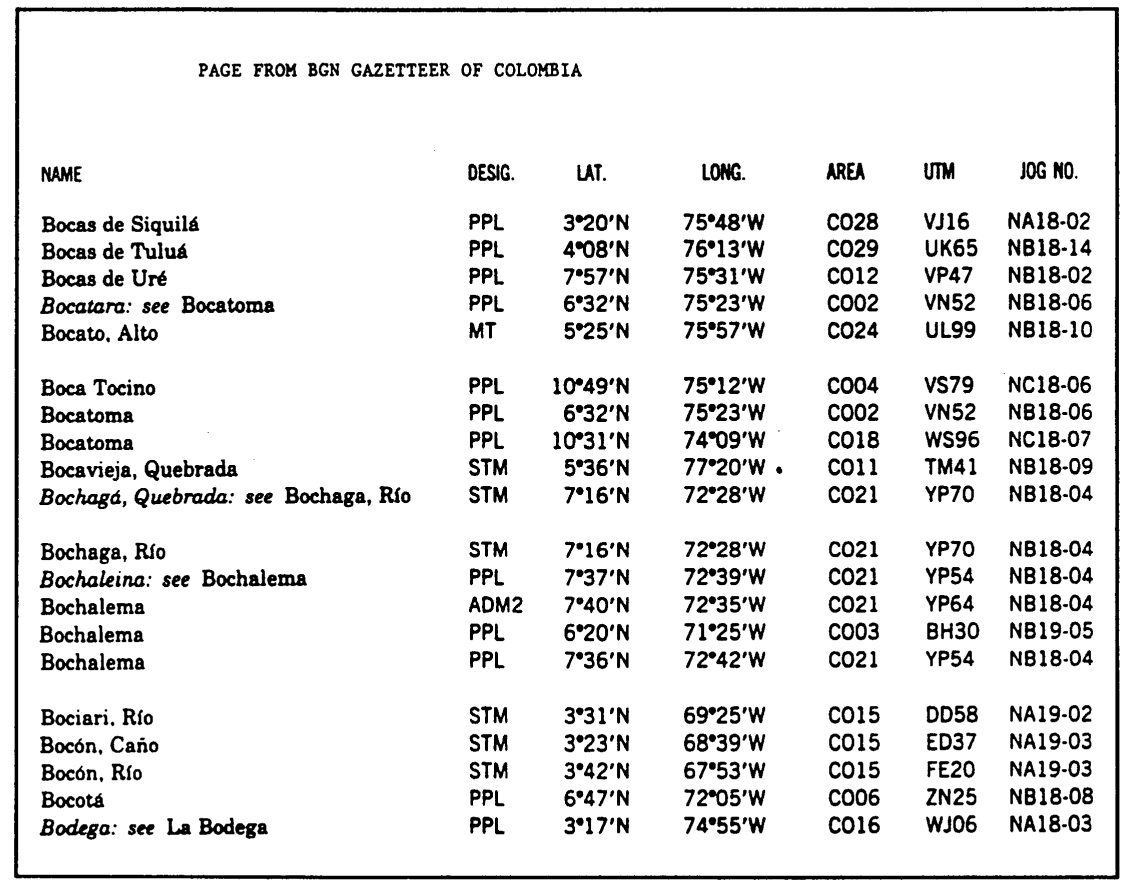

Fig. 2. Facsimile of a part of a page from the BGN Colombia gazetteer. Abbreviations that may be unfamiliar are explained below:

DESIG = Designation, normally abbreviated form of term describing features

PPL = Populated place (city, town, village, settlement, etc.)

MT $=$ Mountain

STM $=$ Stream, river or other flowing body of water

$\mathrm{ADM} 2$ = Second-order administrative area.

AREA = Codes for country and major administrative area in which feature is found UTM = Location on Universe Transverse Mercator projection

JOG NO. = Identification of DMA Joint Operations Graphic in which feature is found

US Board on Geographic Names. The Department of State, represented on the Board, issues Geographic Notes, a publication containing articles on various global geographic issues and also names of foreign countries and geopolitical entities.

\section{Advisory Committees}

In addition to covering foreign areas, the Board has advisory committees to standardize names of places having no sovereignty, specifically Antarctica and undersea areas. The Advisory Committee on Antarctic 


\section{U.S. Board on Geographic Names Work in Foreign Areas 179}

Names has been in existence nearly fifty years and its members have included scientists and research scholars of world renown. The committee works with the National Science Foundation and the U.S. Geological Survey and in 1989 published the fourth edition of the Gazetteer of the Antarctic. The publication has about 3,000 entries. Another body is the Advisory Committee on Undersea Features. It was created in 1964 and also has had members with notable scientific and technical credentials. The Gazetteer of Undersea Features was published this year in its fourth edition. It has about 6,000 names. Other advisory committees in the past have developed romanization systems or have dealt with other specialized aspects of foreign names.

\section{Support of the FNC}

When the 1947 law was enacted, the BGN staff was located in the Department of the Interior. Time brought changes. In 1958, the staff dedicated to the Domestic Names Committee transferred to the U.S. Geological Survey, where it could work more closely with the national topographic mapping program managed by that office. Ten years later, the FNC staff moved to the Army Map Service (AMS) where similar support for the foreign mapping assignments of that agency could be assured. Support of foreign names activity was transferred to the Defense Mapping Agency (DMA) when it was established in 1972.

The FNC staff and the BGN Executive Secretary (who also serves as the FNC Executive Secretary) are DMA employees. The DMA Hydrographic/Topographic Center (HTC) in Brookmont, Maryland (near Washington, D.C.), is the home of the FNC staff while the Executive Secretary works as the DMA Geographer with the DMA Headquarters in Fairfax, Virginia, several miles west of Washington. Two individuals of the staff at HTC also work on the current advisory committees.

The people who make up the FNC staff also work on DMA cartographic programs by preparing names for application to new and revised maps and charts. While names from existing BGN files are used to the maximum, the names experts often have to develop names from other sources. In this way, the names experts (or toponymists) play two important roles in the field of names. 


\section{Romanization}

A vital aspect of standardizing foreign names is to apply romanization systems to spell in the roman alphabet those names of features in countries that do not use a roman writing system. There are many non-roman writing systems, but the Board is concerned only with the major ones. The Board's Romanization Guide, now being prepared as a third edition, lists twenty-three such systems and will replace the second edition of 1972.

In recent years, a number of non-roman-alphabet countries have attempted to develop romanization systems for their languages and to seek international approval of these local systems. While the preparation of native systems appears worthy, before roman-alphabet countries accept new systems, some questions need consideration. Are the systems stable and not subject to frequent change? Do local authorities apply the systems in appropriate ways (e.g., tourist publications, street signs)? Do roman-alphabet countries have an opportunity to consult with the designers of the systems to assure they understand them and, equally vital, to determine whether they could be modified to conform with systems already in use?

In international arenas the Board has emphasized the need to follow such guidelines. Some BGN systems are identical to national systems, but others are different and the Board is naturally eager to maintain the integrity of its systems - many of which have been in use for several decades - rather then abandon them for untested systems.

\section{United Nations Programs in Geographic Names}

In 1959, representatives of the U.S. and other countries met with UN officials to discuss how the UN could promote world communications by adopting a program on names standardization. That meeting produced a program of UN conferences beginning in 1967 and continuing every fifth year with the last one taking place in Montréal in 1987. The BGN Executive Secretary, Dr. Meredith Burrill, was instrumental in formulating numerous plans and continued active through his retirement in 1973; he also attended the 1977 UN conference as the principal U.S. delegate. In addition to UN conferences, a UN Group of Experts on Geographical Names was created to implement UN resolutions and to carry out other programs. Since the author's appointment in 1973 as BGN Executive 


\section{U.S. Board on Geographic Names Work in Foreign Areas 181}

Secretary, he, along with FNC members and staff, has worked closely with the UN. After 1977, BGN members and staff associated with the Board's Domestic Names Committee have also participated in UN programs.

\section{Summary}

Foreign geographic names were not a priority item when the Board on Geographic Names was created, but the requirement soon grew. The people associated with this element of the Board's program - including not only FNC members and the FNC staff but also members and staff of advisory committees working in foreign areas-over the years played significant roles in developing methods for dealing with the highly complex issue of foreign names. Through their professionalism and dedication to the field of geographic names, they accomplished many tasks and contributed importantly to the mission of the Board to serve official U.S. purposes and to meet needs of private, commercial, and institutional bodies as well. They also have played important roles in international programs to standardize names. The work assigned to this element of Board functions is demanding, and, although many members and staff do not receive any particular public acclaim, they should be lauded for their contributions.

Defense Mapping Agency, Fairfax, Virginia

\section{Note}

1. References cited in the text are listed alphabetically in the Works Cited section below. Some of these sources are still available: Gazetteer of the Antarctic from the National Science Foundation; Foreign Names Decisions from the Defense Mapping Agency; Geographic Notes from the Department of State. Gazetteer of Undersea Features may be found at GPO Depository Libraries and may be ordered as a sales item from the Defense Mapping Agency. The four periodic Reports are out of print, as is the Romanization Guide, although a new edition is being prepared. For more information about all of these publications, write to the Executive Secretary, U. S. Board on Geographic Names, 8316 Lee Highway, Fairfax, Virginia 22031.

\section{Works Cited}

United States. Board on Geographic Names. Foreign Names Decisions of the US Board on Geographic Names. No. 20 (April 15, 1990). Washington: Defense Mapping Agency, 1990. 
. Gazetteer of the Antarctic. 4th ed. Washington: National

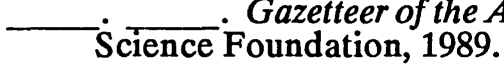

- Gazetteer of Undersea Features. 4th ed. Washington: Defense Mapping Agency, 1990.

State, 1972 .

Romanization Guide. 2nd ed. Washington: Dept. of

Third Report of the United States Board on Geographic Names, 1890-1906. Washington: GPO, 1906.

- Dept. of State. Geographic Notes. Issued Periodically.

. Geographic Board. Fifth Report of the United States Geographic Board, 1890-1920. Washington: GPO, 1920.

Fourth Report of the United States Geographic Board, 1890-1916. Washington: GPO, 1916.

Sixth Report of the United States Geographic Board, 18̄̄0-1932. Washington: GPO, 1933.

\section{$* * * * *$}

\section{Coming in December}

A special issue on Personal Nicknames. Guest editors James K. Skipper, Jr. , and Paul L. Leslie, with contributions by Ted Holland, Jr., Maria Laura Massolo, and Brenda Wilson, and a bibliography of nickname literature compiled by Edwin D. Lawson. 